\title{
APLIKASI SELEKSI CALON PENDONOR DARAH MENGGUNAKAN ALGORITME C4.5
}

\author{
Anisya Sonita ${ }^{1}$, Robian Kundari ${ }^{2}$ \\ ${ }^{1,2}$ Program Studi Teknik Informatika, Fakultas Teknik, Universitas Muhammadiyah Bengkulu \\ Jl. Bali Po. Box, 118 Kota Bengkulu 38119 \\ (Telp 0736-22765 Fak. 0736-26161) \\ ${ }^{1}$ anisyasonita@umb.ac.id \\ ${ }^{2}$ robian. kundari@gmail.com
}

Abstrak: Salah satu masalah utama yang dihadapi dalam sistem pelayanan kesehatan di Negara berkembang, adalah kurangnya persediaan darah aman yang memadai untuk keperluan transfuse darah bagi yang membutuhkannya. Persediaan darah terus berkurang sementara jumlah permintaan darah dari pasien terus meningkat. Unit Transfusi Darah Cabang (UTDC) PMI Kota Bengkulu seringkali mengalami kondisi kritis, yaitu minimnya persediaan darah aman yang dibutuhkan masyarakat. Salah satu cara untuk merestok persediaan darah adalah dengan mengadakan event atau acara penggalangan donor darah yang biasanya dilakukan di area kampus atau bergabung dengan event lain. Banyaknya pendonor membuat proses donor darah menjadi lama karena membutuhkan waktu pada saat proses pemeriksaan kondisi calon pendonor. Kondisi badan calon pendonor darah sangatlah penting agar tidak terjadi hal-hal yang tidak diinginkan setelah proses pengambilan darah selesai. Salah satu efek samping yang sering terjadi akibat mendonorkan darah adalah jatuh pingsan seketika bahkan bisa terjadi gagal jantung sehingga pemeriksaan kondisi badan calon pendonor darah sangatlah penting. Salah satu cara untuk mempercepat pemeriksaan adalah dengan menyimpan data calon pendonor dan melakukan proses mining untuk menentukan kriteria calon pendonor darah potensial. Kriteria tersebut didapatkan dengan cara menggali informasi pendonor darah sebelumnya dan membuat sebuah sistem data mining. Salah satu algoritme yang mendukung proses tersebut adalah algoritme $\mathrm{C} 4.5$ karena dengan menggunakan algoritme ini akan menghasilkan sebuah pohon keputusan yang terdiri dari kriteria-kriteria yang sesuai pendonor darah potensial. Dengan menggunakan kriteria tersebut akan mempercepat proses pemeriksaan calon pendonor. Kata Kunci: Algoritme C4.5, Donor Darah, PMI.

Abstract: A main problem faced in health care systems in the developing countries, is the lack of adequate safe blood supply for the purpose of blood transfusions for those who need it. The blood supply continues to decrease as the amount of blood demand from patients continues to increase. Blood Transfusion Unit Branch (UTDC) PMI Bengkulu often experience a critical condition,that is the lack of safe blood supply needed by society. One way to stack the blood supply is by holding a blood donation event or event that is usually done in the campus area or joining another event. The large number of donors make the blood donor process long because it takes time during the process of examining the condition of the potential donors. The condition of the blood donor body is very important so that no unwated things happen after the blood collection process is complete. One of the side effects that often occur due to blood donation is fainting instantly even heart failure can occur so the examination of the condition of the potential blood donor body is very important. One way to speed up the examination is to keep the data of a potential donor and do the mining process to determine the criteria of potential blood donors. These criteria were obtained by digging up blood donor information and creating a data mining system. One of the algorithms that support the process is the C4.5 algorithm because using this algorithm will produce a decision tree consisting of criteria that suit potential blood donors. Using these criteria will speed up the process of examining potential donors.

Keywords: C4.5 Algorithm, Blood Donors, PMI

\section{PENDAHULUAN}

Salah satu masalah utama yang dihadapi dalam sistem pelayanan kesehatan di negara berkembang adalah kurangnya persediaan darah aman yang 
Jurnal Pseudocode, Volume V Nomor 2, September 2018, ISSN 2355-5920, e-ISSN 2655-1845 www.ejournal.unib.ac.id/index.php/pseudocode

memadai untuk keperluan transfusi darah bagi yang membutuhkannya. Aman dan memadainya persediaan darah dan produknya, bergantung pada dukungan dan komitmen pemerintah terhadap pengembangan pelayanan transfusi darah nasional melalui organisasi yang dikelola pemerintah atau organisasi nirlaba yang ditunjuk seperti Palang Merah Indonesia (PMI) atau organisasi donor darah sukarela [1].

Persediaan darah aman terus berkurang sementara jumlah permintaan darah dari pasien terus meningkat. Unit Transfusi Darah Cabang (UTDC) PMI Kota Bengkulu seringkali mengalami kondisi kritis, yaitu minimnya persediaan darah aman yang dibutuhkan masyarakat. Metode yang digunakan pada kondisi kritis tersebut adalah menghubungi beberapa orang secara acak atau tidak terpola untuk melakukan donor darah demi terpenuhinya bahan baku darah untuk diproses menjadi darah aman yang siap didistribusikan ke masyarakat yang membutuhkannya. Metode tersebut kurang efektif karena data calon pendonor yang terkumpul seringkali tidak memenuhi persyaratan donor darah.

Pemilihan calon pendonor darah potensial dapat dikategorikan sebagai tindakan pengambilan keputusan. Salah satu metode pengambilan keputusan yang sistematis adalah dengan menyusun sebuah pohon keputusan (decision tree).

Daftar calon pendonor darah potensial yang dihasilkan dari proses penambangan data dengan menggunakan algoritme data mining C4.5, selanjutnya perlu dilakukan pemeringkatan sebagai usaha penentuan skala prioritas. Pemeringkatan data tersebut dengan melakukan query yang melibatkan beberapa variabel seperti usia, berat badan, tekanan darah dan kadar HB. Dengan menggunakan algoritme C4.5 akan menghasilkan data berdasarkan kriteria yang di sebut dengan pohon keputusan.

\section{Metode PENELITIAN}

\section{A. Algoritme C4.5}

Algoritme C4.5 adalah algoritme klasifikasi data dengan teknik pohon keputusan yang memiliki kelebihan-kelebihan. Kelebihan ini misalnya dapat mengolah data numerik dan diskret, dapat menangani nilai atribut yang hilang, menghasilkan aturan - aturan yang mudah diintrepetasikan dan tercepat di antara algoritmealgoritme yang lain [2].

Keakuratan prediksi yaitu kemampuan model untuk dapat memprediksi label kelas terhadap data baru atau yang belum diketahui sebelumnya dengan baik. Dalam hal kecepatan atau efisiensi waktu komputasi yang diperlukan untuk membuat dan menggunakan model. Kemampuan model untuk memprediksi dengan benar walaupun data ada nilai dari atribut yang hilang. Begitu juga dengan skalabilitas yaitu kemampuan untuk membangun model secara efisien untuk data berjumlah besar (aspek ini akan mendapatkan penekanan). Terakhir interpretabilitas yaitu model yang dihasilkan mudah dipahami.

Dalam algoritme C4.5 untuk membangun pohon keputusan hal pertama yang dilakukan yaitu memilih atribut sebagai akar. Kemudian dibuat cabang untuk tiap-tiap nilai didalam akar tersebut. Langkah berikutnya yaitu membagi kasus dalam cabang. Kemudian ulangi proses untuk setiap cabang sampai semua kasus pada cabang memiliki kelas yang sama.

Untuk memilih atribut dengan akar, didasarkan pada nilai gain tertinggi dari atribut-atribut yang ada. Gain adalah salah satu atribute selection 
Jurnal Pseudocode, Volume VI Nomor 2, September 2019, ISSN 2355-5920, e-ISSN 2655-1845 www.ejournal.unib.ac.id/index.php/pseudocode

measure yang digunakan untuk memilih test atribute tiap node pada tree. Atribut dengan information gain tertinggi dipilih sebagai test atribute dari suatu node [2]. Untuk menghitung gain digunakan rumus seperti tertera dalam (1) berikut ini:

$\operatorname{Gain}(S, A)=\operatorname{Entropy}(S)-\sum_{i=1}^{n} \frac{|S i|}{|S i|} * \operatorname{Entropy}(S)$

Keterangan:

$S$ : Himpunan kasus

A: Atribut

$n$ : Jumlah partisi atribut $A$

$|S i|:$ Jumlah kasus pada partisi ke- $i$

$|S|$ : Jumlah kasus dalam $S$

Sehingga akan diperoleh nilai gain dari atribut yang paling tertinggi. Sementara itu, penghitungan nilai entropy dapat dilihat pada persamaan 2 berikut ini:

$$
\operatorname{Entropy}(S)=\sum_{i=1}^{n}-p i * \log _{2} p i
$$

Keterangan :

$S$ : Himpunan kasus

$n$ : Jumlah partisi $S$

$p i$ : Proporsi dari Si terhadap $S$

\section{B. Donor Darah}

Donor darah adalah proses menyalurkan darah atau produk berbasis darah dari satu orang ke sistem peredaran orang lainnya. Donor darah berhubungan dengan kondisi medis seperti kehilangan darah dalam jumlah besar disebabkan trauma, operasi, syok dan tidak berfungsinya organ pembentuk sel darah merah [3].

Donor darah secara sederhana adalah penderma darah atau orang yang menyumbangkan darahnya untuk menolong orang lain. Aktivitas donor darah merupakan kewajiban setiap masyarakat sebagai wujud kepedulian terhadap orang lain. Banyak orang yang tidak tahu tentang manfaat donor darah bagi kesehatan. Bahkan ada juga orang enggan mendonorkan darah karena khawatir terhadap efek samping yang ditimbulkannya. Padahal dengan melakukan donor darah, maka sel-sel darah di dalam tubuh menjadi lebih cepat terganti dengan yang baru. Apabila mendonorkan darah tiga bulan sekali, maka kesehatan tubuh tetap terjaga. Selain bermanfaat untuk membantu orang lain, donor darah juga membuat tubuh kita menjadi lebih sehat [2].

\section{Pengertian Pendonor Darah Sukarela}

Pendonor darah sukarela adalah orang yang dan bisa memberi bagian dari tubuhnya untuk orang lain. Penyelenggaraan transfusi darah dilaksanakan atas satu tujuan kemanusiaan dan pada dasarnya kegiatan donor darah adalah untuk menyediakan suplai darah bagi mereka yang membutuhkannya. Meningkatkan kesadaran tentang keselamatan darah dan pentingnya donor sukarela yang akan menjadi fokus dari World Health Organization CITES [3].

Berdasarkan data WHO (World Health Organization) pada tahun 2008 menyatakan bahwa sekitar 75 juta unit darah di dunia dikumpulkan setiap tahun, tetapi hanya $53 \%$ dari yang sukarela, nonpaid donor. Sekitar 18 unit milhon tidak diuji untuk transfusi-jangkit infeksi; WHO mengatakan bahwa diantara 5\% dan $10 \%$ dari kasus infeksi HIV disebabkan oleh transfusi dari kejangkitan darah dan produk darah. WHO berharap menggunakan hari untuk mendorong pemerintah dan kebijakan untuk mencapai pasokan darah yang aman.

Motif yang biasanya melatari orang mendonorkan darahnya antara lain misi sosial atau menolong keluarga. Dari motif-motif tersebut, 
Jurnal Pseudocode, Volume V Nomor 2, September 2018, ISSN 2355-5920, e-ISSN 2655-1845 www.ejournal.unib.ac.id/index.php/pseudocode

pendonor terbaik adalah mereka yang menyumbangkan darahnya secara rutin dan berkesinambungan secara sukarela yaitu sekali dalam tiga bulan.

\section{Jenis-jenis Pendonor Darah Sukarela}

Bahwa masyarakat yang mendonorkan darahnya, dapat dibedakan berdasarkan kriteria pendonor darah [4], sebagai berikut :

a. Donor Keluarga atau Pengganti

Pada sistem ini darah yang dibutuhkan pasien dicukupi oleh donor dari keluarga atau kerabat pasien. Biasanya keluarga diminta untuk menyumbangkan darahnya, dan donor tidak dibayar oleh unit transfusi darah (UTD) atau Rumah Sakit, tetapi mereka mungkin diberi uang atau bayaran dalam bentuk lain oleh keluarga pasien.

\section{b. Donor Komersial}

Donor menerima uang atau hadiah untuk darah yang disumbangkan bahkan mungkin mereka telah memiliki kontrak.

\section{c. Donor Sukarela}

Adalah orang yang memberikan darah, plasma atau komponen darah lainnya atas kerelaan sendiri dan tidak menerima uang atau bentuk pembayaran lainnya, mereka hanya membantu penerima darah yang mereka tidak kenal dan tidak menerima suatu keuntungan. Donor ini tidak dibayar, karena niat si pendonor untuk menolong si pasien itu sendiri. Hal-hal yang biasanya tidak dipandang sebagai pembayaran atau pengganti uang antara lain:

i. Tanda jasa atau penghargaan sederhana, seperti badge atau sertifikat yang tidak memiliki nilai komersil.

ii. Pengganti biaya perjalanan secara khusus harus dilaksanakan dalam rangka menyumbangkan darah.

\section{iii. Pemberian makanan ringan sebelum, selama atau setelah menyumbangkan darah. \\ 3. Manfaat Pendonor Darah Sukarela}

Beberapa keuntungan yang dimiliki donor sukarela dibandingkan dengan jenis donor lain, yaitu:

a) Donor sukarela tidak dalam tekanan untuk menyumbangkan darah, oleh karena itu cenderung lebih memenuhi syarat sebagai donor darah resiko rendah.

b) Donor sukarela bersedia menyumbangkan darah secara teratur, sangat penting untuk menjaga kecukupan persediaan darah.

c) Donor teratur cenderung lebih bebas dari infeksi yang dapat ditularkan melalui transfusi, karena mereka sadar akan pentingnya keamanan darah dan diperiksa setiap mereka menyumbangkan darah.

Donor sukarela cenderung lebih tanggap terhadap himbauan untuk menyumbangkan darah pada keadaan darurat, karena mereka telah menunjukkan kepedulian terhadap donasi darah. Ketersediaan pendonor darah potensial terus meningkat. Terdapat beberapa komponen darah yang hilang sepanjang rangkaian produksi dari perekrutan donor, kehadiran, dan pendarahan yang dialami pendonor dalam proses produksi. Dibutuhkan persyaratan dan potensial untuk meningkatkan ketersediaan produk dengan strategi rekrutmen yang lebih baik, metode produksi, inventori manajemen, dan seleksi penerima [5].

\section{Syarat-syarat Menjadi Pendonor Darah \\ Sukarela}

Pendonor darah harus terlebih dahulu menjalani pemeriksaan kesehatan, baik pengukuran tekanan darah, golongan darah, HB maupun konsultasi medis. Sebagian calon pendonor mungkin berkeinginan untuk 
Jurnal Pseudocode, Volume VI Nomor 2, September 2019, ISSN 2355-5920, e-ISSN 2655-1845 www.ejournal.unib.ac.id/index.php/pseudocode

mendonorkan darahnya, tapi itu semua tergantung dengan jalinan jodoh, sehingga ada yang memenuhi persyaratan untuk mendonorkan darah dan ada yang terpaksa kecewa. Dengan meningkatnya permintaan suplai darah di masyarakat, persediaan darah yang mencukupi dan rasa aman sangat dibutuhkan. Meskipun demikian, perekrutan dan pemeliharaan pendonor darah tetap sebagai tantangan utama bagi organisasi donor darah [6].

Adapun syarat-syarat untuk menjadi penyumbang darah (donor darah) adalah:

a. Umur 17-61 tahun

b. Berat badan $45 \mathrm{~kg}$ atau lebih

c. Tekanan darah $110-160 / 70-100 \mathrm{mmHg}$

d. Kadar HB 12,5 - 16 .

e. Tidak berpenyakit jantung, hati, paru-paru, ginjal, kencing manis, penyakit pendarahan, kejang, kanker, penyakit kulit kronis

f. Tidak hamil, menyusui dan menstruasi

g. Bagi donor tetap, penyumbang darah terakhir minimal 8 minggu yang lalu, maksimal 5 kali setahun

h. Kulit lengan donor sehat

i. Tidak menerima transfusi / komponen darah 6 bulan terakhir dan tidak demam. Tidak menderita penyakit HIV / AIDS

j. Bukan pecandu alkohol/ narkoba

k. Tidak mendapat imunisasi dalam 2-4 minggu terakhir dan tidak demam

1. Tidak digigit binatang yang menderita rabies dalam 1 tahun terakhir

m. Beritahu petugas bila makan aspirin dalam 3 hari terakhir

Pendonor darah harus memenuhi berbagai persyaratan untuk mendonorkan darahnsya, antara lain : memiliki berat badan di atas $50 \mathrm{~kg}$, HB darah sesuai dengan tes, tekanan darah pendonor minimal 110/70 mmhg dan pendonor darah harus beristirahat lebih dari 6 jam sebelum mendonorkan darahnya [4].

\section{HASIL DAN PEMBAHASAN}

A. Hasil

Pada bab ini akan dijelaskan mengenai aplikasi yang dibangun, yaitu aplikasi seleksi calon pendonor darah menggunakan algoritme C4.5. Aplikasi ini lengkapi dengan fasilitas login untuk membatasi user yang bisa mengubah datadata yang ada di dalamnya. Ketika user mengakses aplikasi ini maka akan tampil halaman login seperti pada gambar di bawah ini:

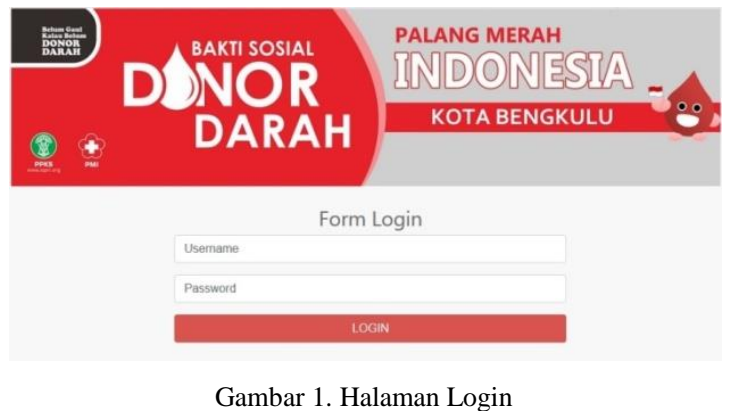

Halaman login ini terdapat form login yang berisi input teks username dan password yang harus diisi dengan benar jika ingin lanjut mengakses aplikasi. Dalam kasus ini gunakan username dan password standar yaitu admin. Setelah proses login berhasil maka aplikasi akan menampilkan halaman home seperti berikut ini:
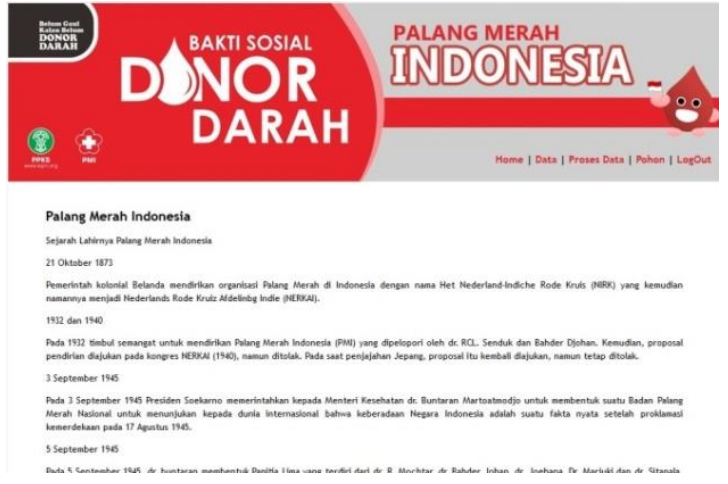

Gambar 2 Halaman Home Aplikasi 
Jurnal Pseudocode, Volume V Nomor 2, September 2018, ISSN 2355-5920, e-ISSN 2655-1845 www.ejournal.unib.ac.id/index.php/pseudocode

Halaman home merupakan halaman dimana aplikasi akan menampilkan informasi singkat mengenai tempat penelitian yaitu sejarah dari PMI (Palang Merah Indonesia) itu sendiri. Halaman ini memiliki menu yang masing-masing menu akan menampilkan halaman yang berkaitan dengan menu yang di maksud. Menu-menu tersebut antara lain adalah menu home yang akan menampilkan halaman home, menu data yang akan menampilkan halaman data pendonor, menu proses data yang akan memulai proses penghitungan algoritme $\mathrm{C} 4.5$, menu pohon yang akan menampilkan halaman yang berisi pohon ketupusan yang diambil berdasarkan perhitungan C4.5 pada halaman sebelumnya dan menu logout yang digunakan untuk keluar dari aplikasi dimana aplikasi akan menampilkan kembali halaman login.
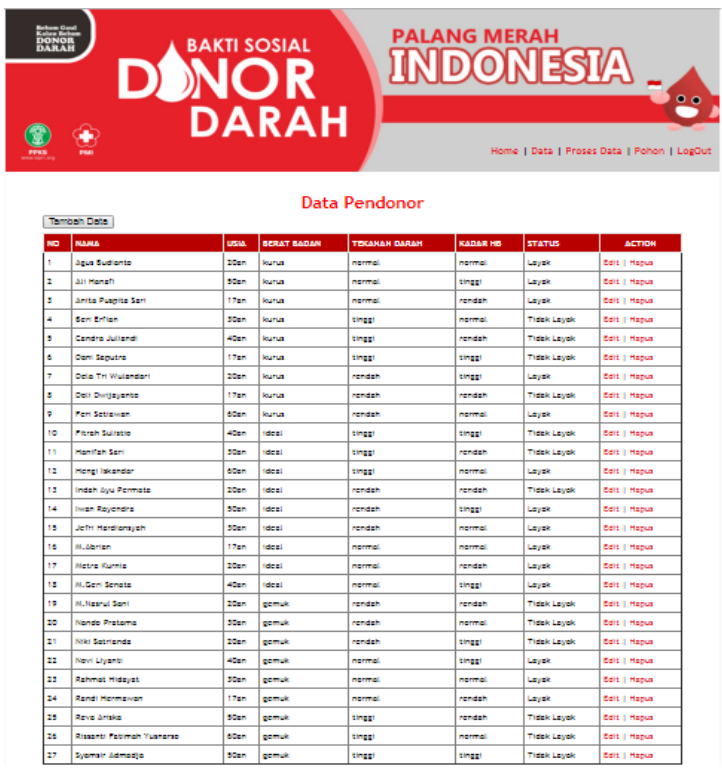

Gambar 3. Halaman Data

Halaman data adalah halaman dimana semua data pendonor akan ditampilkan disini. Halaman ini memiliki menu tambah data, edit data dan hapus data. Jika ingin menambah data maka bisa mengklik tombol tambah data yang terdapat di atas tabel data pendonor.
Halaman tambah data memiliki form input yang berisi input teks nama pendonor, combobox usia, combobox berat badan, combobox tekanan darah, combobox kadar HB darah dan combobox status. Untuk usia berikan pilihan 17an yaitu untuk usia 17-19 tahun, 20an untuk usia 20-29 tahun, 30an untuk usia 30-39 tahun, 40an untuk usia 4049 tahun, 50an untuk usia 50-59 tahun dan 60an untuk usia 60 tahun keatas. Untuk berat badan berikan pilihan kurus, ideal dan gemuk yang mana semua itu bisa dinilai dengan melihat badan pendonor secara langsung. Untuk tekanan darah dan kadar HB berikan pilihan rendah, normal dan tinggi yang mana kedua kategori tersebut bisa di nilai oleh perawat yang memeriksa tekanan darah dan kadar HB pendonor. Untuk status berikan pilihan layak dan tidak layak.

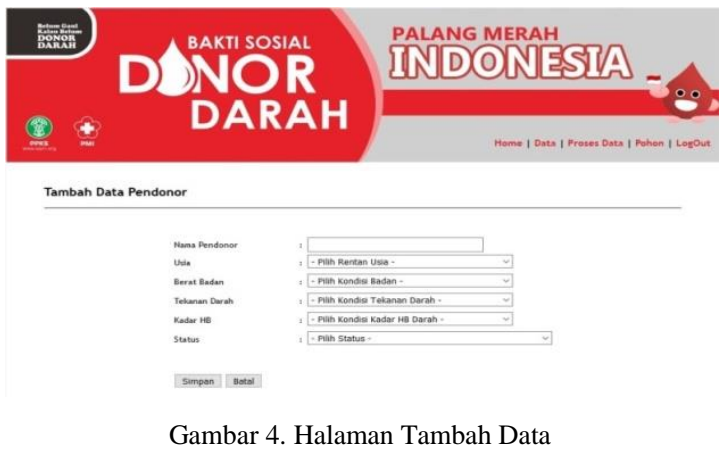

Setelah semua data diisi maka harus klik tombol simpan untuk memulai proses penyimpanan data ke dalam database dan klik batal jika ingin membatalkan proses input data baru. Data yang telah diinput akan tampil di tabel data pendonor yang terdapat di halaman data. Jika terdapat kesalahan pada proses input data maka bisa menggunakan menu edit data yang terdapat di tabel data pendonor. Aplikasi akan menampilkan halaman edit data yang berisikan form tambah data tetapi input teks dan combobox akan terisi dengan data sesuai dengan data dimana menu edit yang di klik. 
Jurnal Pseudocode, Volume VI Nomor 2, September 2019, ISSN 2355-5920, e-ISSN 2655-1845

www.ejournal.unib.ac.id/index.php/pseudocode

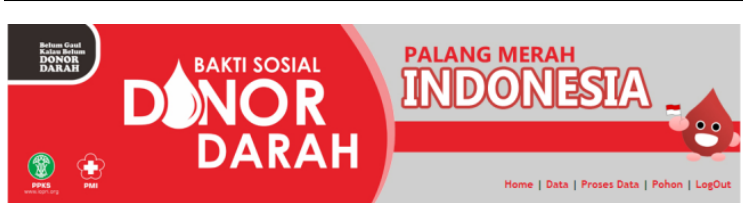

Edit Date

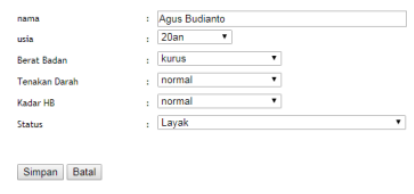

Gambar 5. Halaman Edit Data

Sedangkan menu hapus digunakan untuk menghilangkan data yang ingin dihapus dari dalam database sehingga tidak akan tampil dalam aplikasi. Aplikasi akan memulai proses penghitungan algoritme C4.5 jika menu proses data diklik. Ketika menu diklik maka aplikasi akan menjalankan kode yang terdapat di dalam perhitungan-miningC45.php. Pertama aplikasi akan membaca dan menghitung data pendonor sesuai dengan data atribut yang telah di-set. Aplikasi akan menghitung berapa jumlah layak dan tidak layak dari tiap-tiap atribut. Setelah itu aplikasi akan melanjutkan prosesnya dengan menghitung entropy dan gain sehingga bisa mendapatkan data untuk ditampilkan dalam halaman pohon. Ketika menu proses diklik maka aplikasi akan menampilkan pemberitahuan seperti di bawah ini :

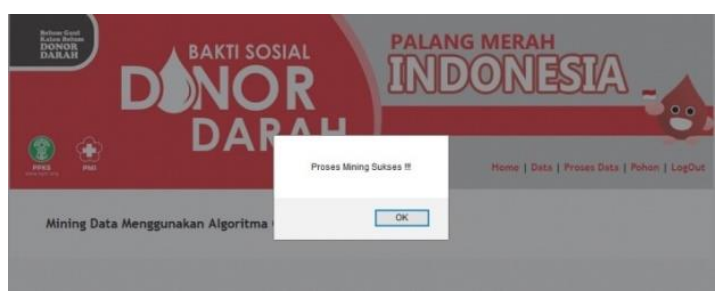

Gambar 6. Windows Alert Proses Berhasil

Ketika tombol OK diklik maka akan tampil halaman seperti di bawah ini:
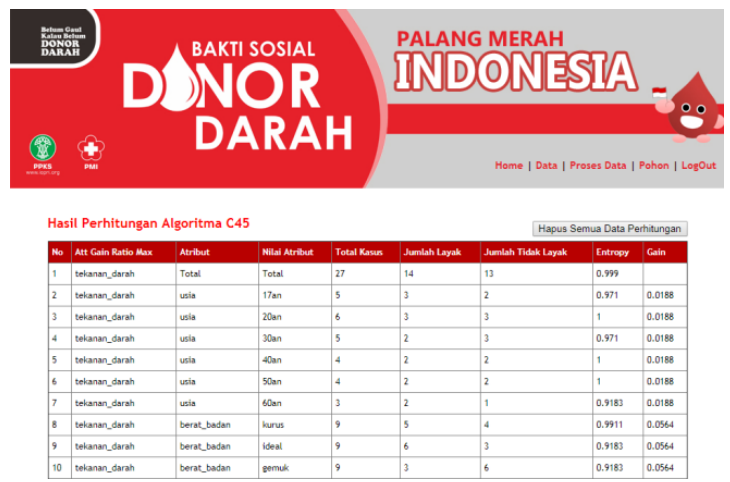

Gambar 7. Halaman Hasil Penghitungan C4.5

Halaman hasil penghitungan C4.5 akan menampilkan tabel yang berisi no, attribut gain ratio max, atribut, nilai atribut, total kasus, jumlah layak, jumlah tidak layak, entropy dan gain. Proses penghitungan nanti akan di jelaskan pada sub bab pembahasan. Halaman ini menyediakan tombol hapus semua data perhitungan yang berfungsi untuk mengosongkan tabel iterasi yang terdapat di dalam database.

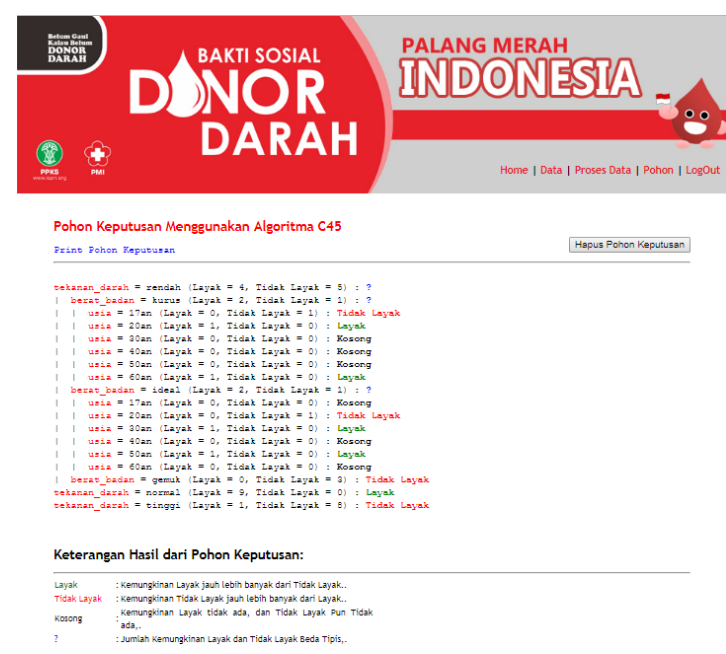

Gambar 8. Halaman Pohon

\section{KESIMPULAN}

Berdasarkan hasil dari penelitian yang telah dilakukan, maka dapat ditarik kesimpulan sebagai berikut:

1. Algoritme C4.5 berhasil diimplementasikan pada aplikasi calon pendonor darah. 
Jurnal Pseudocode, Volume V Nomor 2, September 2018, ISSN 2355-5920, e-ISSN 2655-1845 www.ejournal.unib.ac.id/index.php/pseudocode

2. Berdasarkan pengujian yang telah dilakukan menyatakan bahwa aplikasi yang dibangun berfungsi dengan baik.

3. Berdasarkan hasil pengujian dari data pendonor yang ada menghasilkan keputusan bahwa pendonor potensial adalah pendonor dengan tekanan darah normal. Jika pendonor memiliki tekanan darah rendah maka harus diikuti dengan berat badan yang kurus atau ideal sedangkan jika berat badan gemuk maka sebaiknya jangan mendonorkan darahnya karena bisa mengakibatkan efek samping yang tidak baik. Untuk pendonor yang memiliki tekanan darah tinggi tidak diperkenankan untuk mendonorkan darahnya.

\section{REFERENSI}

[1] Yuyun, Soedarmono, SM, Susanti dan Kartabrata. 2005. Pedoman Pelayanan Transfusi Darah: Perhitungan Biaya Unit Transfusi Darah UTDP PMI, Jakarta

[2] Kusrini, luthfi taufiq emha, 2009, Algoritme Data Mining. Penerbit Andi. Yogryakarta.

[3] Depkes RI, 2009. Sistem Kesehatan Nasional. Jakarta.

[4] Aziz, A. S. 2000. Upaya Menghimpun dan Melestarikan Donor Darah. Buletin Transfusi Darah No.279/November Tahun ke XXVII. UTD-PMI Pusat. Jakarta.

[5] Trevor J. Cobain. 2004. Fresh Blood Product Manufacture, Issue, and Use: A Chain of Diminishing Returns? Transfusion Medicine Reviews. Vol 18. No 4. pp 279292.

[6] Masser, B.M., White, K.M., Hyde, M., \& Terry, D.J. (2008). The psychology of blood donation: Current research and future directions. Transfusion Medicine Reviews, 22, 215-233. 